\title{
Interleukin-6 Production by Macrophages from BALB/c Mice with a Chronic Infection of Lactic Dehydrogenase Virus
}

\author{
Hiroyuki IWATA and Toshiharu HAYASHI* \\ Laboratories of Veterinary Hygiene and *Pathology, Faculty of Agriculture, \\ Yamaguchi University, 1-1,677 Yoshida, Yamaguchi 753, Japan
}

(Received 25 January 1994/Accepted 13 April 1994)

\begin{abstract}
The production of interleukin-6 (IL-6), which is known as a B cell differentiation factor, by peritoneal macrophages from mice with a chronic lactic dehydrogenase virus (LDV) infection was compared with that from uninfected mice. The same amounts of IL6 were detected in the culture supernatant of macrophages from LDV-infected mice as those from uninfected mice. Furthermore IL-6 production of macrophages from LDVinfected and uninfected mice was not affected by the addition of indomethacin. These results suggested that many immunological alterations seen in LDV-infected mice may not be due to, at least in part, altered IL- 6 production ability of macrophages and the IL- 6 production may not be affected by cyclooxygenase-derived products. - KEY WORDS : IL-6, LDV, macrophage, mouse
\end{abstract}

Lactic dehydrogenase virus (LDV), a member of unclassified Togaviridae, infects subpopulations of macrophages in mice [14]. LDV infection alters a variety of humoral and cellular immune responses to several exogenous and endogenous antigens during acute and chronic phases of infection, and infected mice show a persistent viremia and increased level of several kinds of enzymes including lactic dehydrogenase without any clinical or pathological changes $[14,17]$. For example, in chronically LDV infected mice, responses to $\mathrm{T}$-cell dependent antigens are depressed [17]. Moreover, LDV infection inhibits autoantibody production against DNA and nuclear antigens $[5,6,16]$. However, the mechanisms which suppress antibody production are largely unknown in LDV-infected mice. It is well known that humoral responses are regulated by immunocompetent cells and cytokines cooperation. It has been reported that interleukin-6 (IL-6), which is produced by several cells including macrophages, mediates the terminal differentiation of activated $B$ cells [9]. Thus, IL-6 is considered to be a key cytokine for antibody production. In this brief note, we investigated IL- 6 production by macrophages, and the effect of indomethacin on IL-6 production by macrophages, since macrophage function is usually affected by cyclooxygenase products in LDV-infected mice $[4,5]$.

Male 5-weeks old BALB/c AnNCrj mice (Charles River Co., Kanagawa, Japan) were infected intraperitoneally (i.p.) with LDV $10^{5.5}$ $\mathrm{ID}_{50}$ (kindly supplied by Dr. A.L. Notkins, NIDR, NIH, USA [8]). Animals which had been infected with LDV for 3 months were used. Groups of five mice of the same age and approximately same weight were used for each experiment. Peritoneal macrophages were obtained by the methods described previously [4]. In brief, mice infected with or without LDV were injected with thioglycolate $(5 \%, 1.5$ me ; Difco, Detroit, MI, USA) i.p., and 4 days later exudate cells were collected, pooled, and placed on plastic dishes $(60 \mathrm{~mm}$ in diameter). The cells were incubated for $2 \mathrm{hr}$ at $37^{\circ} \mathrm{C}$ in a $5 \% \mathrm{CO}_{2}$ atmosphere as described previously [4]. After incubation, adherent cells were scraped and resuspended in Dulbecco's modified Eagles' medium (DMEM) with 5\% heatinactivated fetal calf serum (FCS). The viabi- 
A

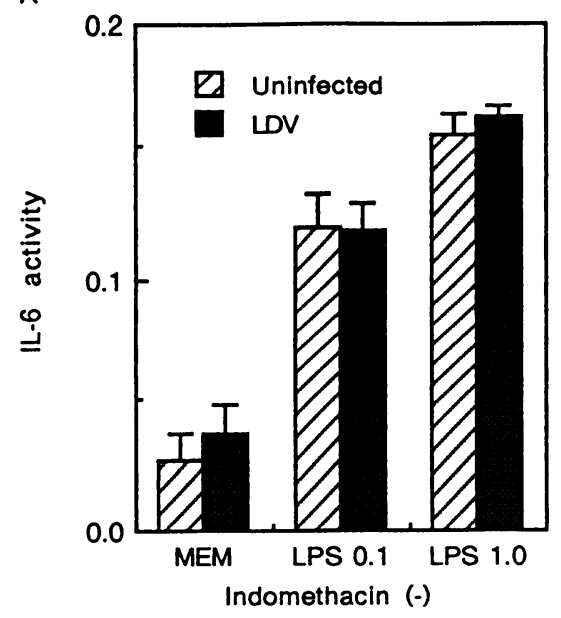

B

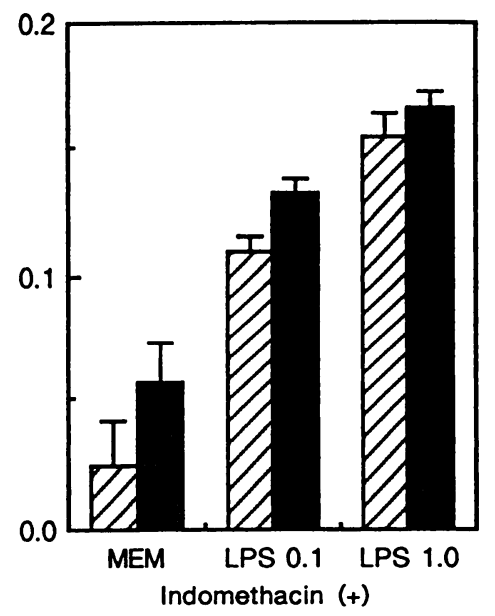

Fig. 1. Interleukin-6 (IL-6) activity in the culture supernatant of macrophages from LDV-infected and uninfected mice $(A)$ and that when indomethacin was added (B). (-) indicates no addition of indomethacin. (+) indicates addition of indomethacin. Each point represents the mean \pm S.D. of optical density for triplicate assays.

lity and purity were more than 95\% using trypan blue dye exclusion. Macrophages were cultured $\left(2 \times 10^{6}\right.$ in $10 \mathrm{~m} \ell$ DMEM + FCS $)$ with or without lipopolysaccharide (LPS ; Escherichia coli type 026 : B6, Sigma Co., St. Louis, MO, USA ; 0.1 or $1.0 \mu \mathrm{g}$ ) for $24 \mathrm{hr}$ at $37^{\circ} \mathrm{C}$ in a humidified $5 \% \mathrm{CO}_{2}$ atmosphere. The cells were also incubated with or without indomethacin $\left(10^{-6} \mathrm{M}\right)$ (Sigma Co., St.Louis, MO, USA) . Indomethacin was dissolved in a small volume of ethanol and adjusted to the desired concentration by PBS. The concentration of ethanol was less than $0.05 \%$ in all incubations and did not affect cell viability as determined by trypan blue dye exclusion. Incubations without indomethacin received a similar concentration of ethanol. Samples were assayed for IL-6 activity using hybridoma cell, B3B1 (kindly supplied by Dr. A. Hasegawa, The University of Tokyo, Japan [15]) by the methods described previously [12]. B3B1 cells were suspended in RPMI1640 medium supplemented with 10\% heat-inactivated FCS, antibiotics $(100 \mathrm{U} / \mathrm{m} \ell$ penicillin, $100 \mu \mathrm{g} / \mathrm{m} \ell$ streptomycin), $5 \times 10^{-5} \mathrm{M}$ 2 -mercaptoethanol, and $10 \mathrm{mM}$ HEPES. The cells were cultured in the presence of $20 \%$ (v/ v) samples for $24 \mathrm{hr}$ at $1 \times 10^{4}$ cells (in $100 \mu \mathrm{l}$ ) per well in a flat-bottomed Falcon Microtest II tissue culture plate (Becton Dickinson Co., NJ, U.S.A.) . Cultures were pulsed with $10 \mu l$ of 3-(4,5-dimethylthial-2-yl)-2,5-diphenyltetrazolium bromide (MTT ; Sigma Co., MO, U.S.A.) solution dissolved in PBS at $5 \mathrm{mg}$ per $\mathrm{m} \ell$ and incubated for $4 \mathrm{hr}$. At the end of incubation, $0.04 \mathrm{~N} \mathrm{HCl}$-isopropanol was added to each well and mixed to dissolve the dark blue crystals. The plates were read by an ELISA reader at a test wavelength of $570 \mathrm{~nm}$ and a reference wavelength of $630 \mathrm{~nm}$. The standard deviations (S.D.) of the means were determined and were analysed by Students' $t$ test. Each point represents a mean \pm S.D. Differences between means were considered to be significant at $\mathrm{P}<0.05$.

Since LPS is a potent inducer of IL-6 [19], IL-6 activity in the culture supernatant of macrophages with LPS was examined. As shown in Fig. 1A, macrophages without LPS do not produce IL-6, but macrophages with LPS in both LDV-infected and uninfected mice produced IL-6 ( $\mathrm{P}<0.05$; comparison between LPS-treated and untreated macrophages) in a dose-dependent manner. Also there are no differences in production of IL-6 from macrophages between uninfected and infected groups. The viability of the cells from both groups was more than $90 \%$ and LDV-infected cells were less than $5 \%$ within the assay period (data not shown). Indomethacin, which is a strong inhibitor of prostaglandins of $\mathrm{E}$ series 
(PGEs) [20], was added to culture medium of macrophages stimulated with LPS. As shown in Fig. 1B, there is no difference between IL6 activities with and without indomethacin.

Most functional alterations of macrophages may be due to cyclooxygenase products after interaction between $\mathrm{IC}$ and $\mathrm{Fc}$ receptor on macrophages other than direct viral infection in chronically LDV-infected mice $[4,7]$, since macrophages infected with LDV were less than $10 \%$ [10]. Unexpectedly, IL-6 production by macrophages is not impaired in the chronic infection of mice, suggesting that the depressed humoral response to $\mathrm{T}$ cell dependent antigens seen in chronic phase of infection [17] may not be involved in the depressed IL-6 production by macrophages as reported here. Moreover, the present results suggest that cyclooxygenase products, especially PGEs, one of the regulators of macrophage function such as Ia antigen expression $[5,18]$, IL-1 production [4], and spreading, adhesion and migration [2], may not affect IL- 6 production. In addition, though LDV infection causes suppression of autoimmune diseases $[3,5,6,10,16]$, these phenomena may not be due to, at least in part, impaired macrophage IL-6 production, which is known as an enhancer of autoimmune diseases $[1,9]$. We could not eliminate the possibility that IL6 production from other immunocompetent cells especially helper T2 cells [13] might be suppressed, since it has been suggested that defective helper $T$ cell function was reported in chronically LDV-infected mice [11]. Further study is needed to clarify these points including IL-6 activity in the blood.

This study was supported in part by a Grant-in-Aid (No. 06660381) for Scientific Research from the Ministry of Education, Science and Culture in Japan.

\section{References}

[1] Alarcon-Riquelme, M.E., Moller, G., and Fernandez, C. (1993). Clin. Exp. Immunol., 91, 220-225.

[2] Cantarow, W. D., Cheung, H. T., and Sundharadas, G. (1978) Prostaglandins, 16, 39-46.

[3] Hayashi, T., Hashimoto, T., and Kameyama, Y. (1994). Int. J. Exp. Pathol., 75, 117-121.

[4] Hayashi, T., Iwata, H., Hasegawa, T., Ozaki, M., Yamamoto, H., and Onodera, T. (1991). J. Comp. Pathol., 104, 161-170.

[5] Hayashi, T., Mori, I., and Yamamoto, H. (1992). Int. J. Exp. Pathol., 73, 593-601.

[6] Hayashi, T., Noguchi, Y., and Kameyama, Y. (1993). Int. J. Exp. Pathol., 74, 553-560.

[7] Hayashi, T., Onodera, T., and Yamamoto, H. (1992). J. Comp. Pathol., 107, 35-40.

[8] Hayashi, T., Salata, K., Kingman, A., and Notkins, A. L. (1988). Am. J. Pathol., 132, 503-510.

[9] Hirano, T., Taga, T., Yasukawa, K., Nakajima, K., Nakano, N., Takatsuki, F., Shimizu, M., Murashima, A., Tsunawa, S., Sakiyama, F., and Kishimoto, T. (1987). Proc. Natl. Acad. sci. U.S. A., 84, 228-231.

[10] Inada, T. and Mims, C. A. (1985). Arch. Virol., 86, 151-165.

[11] Michaelides, M. C. and Simms, E. S. (1980). Cellular Immunol., 50, 253-260.

[12] Mosmann, T. (1983). J. Immunol. Methods, 65, 5563.

[13] Mosmann, T. R. and Coffman, R. L. (1989). Adv. Immunol., 46, 111-147.

[14] Notkins, A. L. (1971). Am. J. Pathol., 64, 733-746.

[15] Ohashi, T., Goitsuka, R., Ono, K., and Hasegawa, A. (1989). J. Leucocyte Biol., 46, 501-507.

[16] Oldstone, M. B. A. and Dixon, F. J. (1972). Sci. ence, $175,784-786$

[17] Rowson, K. E. K. and Mahy, B. W. J. (1985). J. Gene. Virol., 66, 2,297-2,312.

[18] Snyder, D. S., Beller, D. I., and Unanue, E. R. (1982). Nature, 299, 163-165.

[19] Van Damme, J., Van Beeumen, J., Decock, B., Van Snick, J., De Ley, M., and Billiau, A. (1988). J. Immunol., 140, 1,534-1,541.

[20] Vane, J. R. (1971). Nature (New Biology) , 231, 232 235 . 
慢性乳酸脱水素酵素ウイルス感染 BALB/c マウスにおける マクロファージのインターロイキン 6 産生

岩田祐之・林 俊春*

山口大学農学部家畜衛生学教室

*山口大学農学部家畜病理学教室

慢性乳酸脱水素酵素ウイルス (LDV) 感染マウスに おけるマクロファージからのインターロイキン 6 (IL6）産生を非感染マウスのそれと比較した。LDV 感染 マウスにおけるマクロファージの IL-6産生能は非感染 マウスのものと同等であり，またインドメタシンの添 加により影響されなかった。以上の結果から, 慢性
LDV 感染マウスにみられる多くの免度反応の修飾は少 なくともマクロファージの IL-6産生能の変化によるも のではないこと, また, この IL-6産生はシクロオキシ ゲナーゼ経路由来産物に影響されないことが示唆され た。 